\title{
Revista da Faculdade de Direito
}

\section{DOUTRINA}

\section{Quae temporaria sunt ad agendum, perpetua sunt ad excipiendum}

\section{Francisco Morato}

Em principio fenecem as exceções desde que se extingue o direito sobre que se fundam ou que cessa uma das condições essenciaes de sua existencia.

Não se extinguem, porém, pela prescrição. Desde que o direito continua a subsistir, absurdo seria negar os meios de fazel-o valer em juizo; razão de irresistivel procedencia juridica, a que acrescem outras de equidade e bom senso, já porque a prescritibílidade das exceções implicaria a validação de atos insanavelmente nulos, já porque, se nos é facultado acionar quando bem nos apraz, não podemos entretañto, entrar com exceção senão quando o adversario nos chama em justiça.

Fundada nestes canones de processualistica e de civilismo, formulou a escola o axioma juridico - quae ad agendum sunt temporalia, ad excipiendum sunt perpetua - , axioma que os romanos guardavam com a costumada sabedoria, que é de exação absoluta no Direito Moderno e que se manifesta por consequencias praticas palpaveis (Maynz: Droit Romain, I, § 151. Aubry \& RaU: Droit Civi'. VIII, § 771). 
Contra o sabio brocardo revoltam-se Laurent, Duranton, Marcadé e, entre nós, Jỗo Monteiro, Gusmão e outros, pelo fundamento que invocam, de ser inconsistente, diametralmente oposto a principios rudimentares de direito.

A jurisprudencia e a torrente dos interpretes sustentam, porém, a boa doutrina, podendo-se declinar dentre os mestres franceses, os insignes Aubry \& Rau, Merlin, Toullier, Larombiere, Demolombe e o proprio Planiol, o qual, depois de escrever menos avisadamente não existir hoje a razão que em direito romano justificava a máxima, conclue combatendo o parecer de Laurent e testemunha que uma jurisprudencia constante considera a exceção como perpetua e sobreviventée consequencialmente á extinção da ação por prescrição (Traité de Droit Civil, llème éd. Rinert, II 11291 e not 1).

O que a lei extingue em algumas hipoteses, conforme acontece com a rescisoria, é a ação por esse processo especial e não a defesa do direito pelas vias ordinarias.

Por garantia do direito, quando violado ou ameaçado, a lei dá ao titular a faculdade de assegural-o por via direta ou indireta, por ação ou por exceção, agindo ou defendendo.

Ás vezes a lei, por conveniencia de evitar a multiplicação de feitos, limita no tempo o direito de agir; mas não limita o de defender, porque o direito, emquanto é direito, ha-de ter necessariamente garantia.

É o que acontece no caso da ação rescisoria. Vindo a lanço um ato contamïnado de nulidade visceral, póde a parte arguil-a dentro do prazo de recurso no feito em que ela ocorreu. Não arguindo em recurso, póde pleiteal-a por ação rescisoria afim de evitar o estorvo eventual do ato nulo. Não entrando com a rescisoria dentro de cinco annos, perde o direito á ação, mas não perde o direito á defesa. Porisso mesmo que é insanavel, a nulidade não se sana, nem o ato se revalida; pelo que lhe é licito impugnal-o em qualquer tempo e instancia em que se tente fazel-o prevalecer contra si. 
Como é sabido, o fundamento da ação rescisoria é a circunstancia de achar-se a sentença rescindenda contaminada de nulidade absoluta, que não pode ser sanada, ratificada ou suprida pelo Juiz, nem mesmo a requerimento das partes.

Si vem a ponto uma dessas nulidades e contra ela não entra a parte tempestivamente com a rescisoria, como por essa omissão revalidal-a e consideral-a sanada?

Absurdo chocante.

O que a lei faz na conjuntura exposta e em outras analogas, é eliminar o processo especifico para o caso, sem todavia aniquilar o direito e prival-o de defesa por vias ordinarias.

É neste sentido que se diz serem em regra perpetuas as exceções, tomando o termo no sentido geral da defesa. Subordinadạs á ação do autor, duram tanto tempo quanto as ações que tendem a repelir.

E o sentido do brocardo de exação apodictica quae temporalia sunt ad agendum, perpetua sunt ad excipiendum (Ramalho: Praxe, § 234. Maynz: Droit Romain, I $§ 151$. Aubry \& Rau, Droit Civil, 4ème ed., § 771. Planiol II pag. 485).

Em apoio da tese verdadeira, assinala Maynz um exemplo frisante. Em $1855 A$ vende a $B$ uma casa, sob a condição de ser o imovel entregue no ato e o preço pago em 1857. Nenhuma das partes executa o contrato, cabendo a cada uma a ação resultante da venda e a exceptio non adimpleti contractus. Entretanto a ação do comprador prescrever-se-á em 1875, a do vendedor em 1877. Supondo que o vendedor demande em 1876 o pagamento do preço, poderá o comprador, cuja ação acha-se prescrita ha um ano, fazer valer sua exceptio non adimpleti contractu? Esta questão não comporta duvida conforme a tese verdadeira; os adversarios do bom sistema, ao contrario, são obrigados a condenar o comprador a pagar o preço sem receber a casa (Droit Romain cit., not. 6 ao $\S 151$ ). 
Criticando uma das decisões da Corte de Cassação de Pariz, no sentido de que a regra formulada na escola dos romanistas é maxima de equidade e de bom senso, pergunta LAURENT si é licito aos tribunaes derogar e fazer a lei em nome da equidade e do bom senso.

A critica realça a semrazão do ponto de vista do ilustre e fecundo jurisconsulto belga. Não ha lei nenhuma, nem na doutrina romana, nem no direito positivo francês nem no direito patrio, exținguindo por prescrição no caso o direito a que a ação se refere. o que a lei faz é limitar no tempo a ação creada para hipoteses especificas, sem tocar no direito que póde ser invocado e patrocinado pelas vias comuns de defesa.

Em regra a extinção obliqua do direito, por consequencia da extinção da ação com que o tutela o direito, só se opera nos casos geraes ou ordinarios de prescrição dos remedios judiciarios.

Si lei nenhuma extingue o direito a que alude a ação especifica, é evidente que rege na conjuntura o principio geral de doutrina processual, de que a todo direito corresponde necessariamente a faculdade de fazel-o valer em justiça e de que, si não houvera tal principio geral, caberia invocar a equidade e bom senso juridico em um de seus mais notaveis predicados ou virtualidades, qual seja de suprir as dificiencias e lacunas da legislação positiva.

Costumam os partidarios de Durauton e Laurent padrinhar-se com varios exemplos, que são antes de prazos extintivos que de prescrição e que logicamente não se aplicam ao têma em controversia.

A maxima quae temporalia sunt ad agendium, perpetua sunt ad excipiendum não é aplicavel em materia de decadencia de prazos (Clovis BevilaQua: Com. ao art. 161 do Cod. Civil. Aubry \& Rau cit., § 771).

De todo o exposto resulta, manifesta e irrefutavel, na doutrina do Direito Romano e na doutrina do Direito Moderno, na teoria e na pratica, a verdade e sabedoria da maxima que vimos defendendo. 